\title{
Dactylogyrids (Monogenea) parasitic on cichlids from northern Brazil, with description of two new species of Sciadicleithrum and new host and geographical records
}

\author{
Fabiano Paschoal'1, Tomáš Scholz², Marcos Tavares-Dias ${ }^{3}$ and José L. Luque ${ }^{4 *}$ \\ ${ }^{1}$ Programa de Pós-Graduação em Biologia Animal, Universidade Federal Rural do Rio de Janeiro Rodovia BR 465 - Km 07, \\ Seropédica, RJ, CEP 23.890-000, Brazil; ${ }^{2}$ Institute of Parasitology, Biology Centre of the Czech Academy of Sciences, Branišovská 31, \\ 37005 České Budějovice, Czech Republic; ${ }^{3}$ Laboratório de Aquicultura e Pesca, Embrapa Amapá, Caixa Postal 10, CEP 68903-419, \\ Macapá, AP, Brazil; ${ }^{4}$ Departamento de Parasitologia Animal, Universidade Federal Rural do Rio de Janeiro, Caixa Postal 74540, \\ Seropédica, RJ, CEP 23.851-970, Brazil
}

\begin{abstract}
Two new species of Sciadicleithrum Kritsky, Thatcher and Boeger, 1989 are described from two cichlids from the Araguarí River, State of Amapá, northern Brazil. Sciadicleithrum edgari n. sp. from Satanoperca jurupari (Heckel, 1840) differs from all congeneric species in the morphology (hook-shaped, with middle process and distally bifurcate) of the accessory piece of the male copulatory organ (MCO). Sciadiclethrum araguariensis n. sp. from Crenicichla labrina (Spix and Agassiz, 1831) can be distinguished from all other species by a Y-shaped accessory piece of MCO. In addition to the description of two new species, new host and geographical records of six dactylogyrid monogeneans from cichlid fishes are presented.
\end{abstract}

\section{Keywords}

Monogenea, Dactylogyridae, Sciadicleithrum, Cichlidae, Araguari River, Xingu River, neotropics

\section{Introduction}

Monogeneans, especially dactylogyrids (Dactylogyridae: Ancyrocephalinae), are the most species-rich group of metazoan ectoparasites of freshwater fishes in the Neotropical region (Thatcher 2006; Mendoza-Franco et al. 2010; Cohen et al. 2013). Fishes of the family Cichlidae are a diverse group of commercial importance as food and ornamental fishes (Ortega et al. 2007; Perez-Sanchez and Páramo-Delgadillo 2008). In the Neotropical region, native cichlids are parasitised by dactylogyrid monogeneans of the genera Gussevia Kohn and Paperna, 1964 (17 species described from cichlids in South America); Sciadicleithrum Kritsky, Thatcher and Boeger, 1989 (24 spp. occurring also in Central America and Neotropical Mexico); Trinidactylus Hanek, Molnar and Fernando, 1974 (one species limited to the Caribbean); and Tucunarella Mendoza-Franco, Scholz and Rozkošná, 2010 (also monotypic, with the only record from the Peruvian Amazonia) (Vidal-Martínez et al. 2001; Bellay et al. 2009; MendozaFranco et al. 2010).
As part of the current effort to map the diversity of metazoan ectoparasites of freshwater fishes in the Neotropical Region (see e.g. Mendoza-Franco et al. 2010; Mendoza-Palmero et al. 2012; Braga et al. 2014), cichlid fishes from two localities in northern Brazil, the Xingu River in Altamira, a principal southern tributary of the Amazon River, and the Araguari River, which enters the Atlantic Ocean just north of the Amazon River estuary, were examined. In the present paper, two new species of Sciadicleithrum are described and new host records of other dactylogyrid monogeneans are presented.

\section{Materials and Methods}

A parasitological survey was carried out in two river basins in northern Brazil between April and May 2013. The hosts were collected by local fishermen in Altamira, State of Pará and Ferreira Gomes, State of Amapá. The gills were excised and placed in Petri dishes with tap water and examined for monogeneans with the use of a stereomicroscope. Monogeneans 
found were fixed in a mixture of glycerin ammonium picrate (GAP) to study sclerotised structures (Malmberg 1957). After morphological evaluation, the specimens fixed in GAP were remounted in Canada balsam following the procedure of $\mathrm{Er}$ gens (1969). Other specimens were fixed in hot $4 \%$ formalin, stained with Gomori's trichrome and mounted in Canada balsam to study internal organs. In morphological descriptions, measurements are in micrometres, the ranges followed by the mean and number of measurements (n) in parentheses. Drawings were made with the aid of an Olympus BX53 microscope (Olympus Corporation, Tokyo, Japan) equipped with a drawing tube. The description of the male copulatory organ (MCO) follows Kritsky et al. (1985) and Bellay et al. (2009). The abbreviations $S c$. for the parasites (Sciadicleithrum) and $S a$. for the hosts (Satanoperca) are used to avoid doubt as to the genera. For comparative purposes and based on the similarity with the new taxa, the following specimens deposited in the Helminthological Collection of Institute Oswaldo Cruz (CHIOC) of Rio de Janeiro, Brazil, were examined: Sciadicleithrum joanae Yamada, Takemoto, Bellay and Pavanelli, 2009 (CHIOC 37161, holotype; CHIOC 37163 a-b, 2 paratypes); Sciadicleithrum satanopercae Yamada, Takemoto, Bellay and Pavanelli, 2009 (CHIOC 37165a, holotype; CHIOC 37166a and 37167, 2 paratypes).

Type and voucher specimens of monogeneans found in the present study were deposited in the Helminthological Collection of Institute Oswaldo Cruz (CHIOC) of Rio de Janeiro, Brazil and the Helminthological Collection of the Institute of Parasitology, Biology Centre of the Czech Academy of Sciences, České Budějovice (acronym IPCAS), as indicated in the respective descriptions. Scientific and common names of host are those provide in FishBase (Froese and Pauly, 2015).

\section{Family Dactylogyridae Bychowsky, 1933 Subfamily Ancyrocephalinae Bychowsky, 1937}

\section{Sciadicleithrum edgari n. sp. (Fig. 1 A-H)}

Description (based on 7 specimens): Body fusiform, 406$510(442 ; \mathrm{n}=5)$ long including haptor; greatest width 90 $99(95 ; n=4)$, at level of ovary. Anterior region with 3 bilateral pairs of head organs; cephalic glands distinct, anterolateral to pharynx. Eyespots 4, with posterior pair being larger; accessory granules scattered in cephalic region. Pharynx spherical, 16-21 $(18 ; \mathrm{n}=4)$ in diameter; oesophagus short; intestine bifurcates closely posterior to pharynx; caeca confluent posterior to testis, without diverticula. Haptor globose, $34-52(45 ; n=5)$ wide; armed with 2 pairs of anchors, 2 bars and 7 pairs of similar hooks. Ventral anchor 24-27 $(25 ; \mathrm{n}=6)$ long, with elongate superficial root, short deep root and curved shaft and point; base width 21-24 (23; $n=$ 6). Dorsal anchor 37-41 $(39 ; n=6)$ long, with elongate welldeveloped superficial root, poorly developed deep root and curved shaft and point; base width $27-30(28 ; n=6)$. Ventral bar 29-32 $(30 ; n=6)$ long, slender, with delicate umbelliform membranes and enlarged ends. Dorsal bar 27-29 (28; $\mathrm{n}=6$ ) long, winding, with enlarged ends. Hooks 14, similar, each with erected thumb, relative robust point, FH loop $3 / 4$ shank length; total length $15-18(16 ; n=6)$. Male copulatory organ (MCO) comprising a delicate coil of $2 \frac{1}{2}$ clockwise rings with diameter of proximal coil 14-16 $(15 ; \mathrm{n}=5)$ long; copulatory tube with $87-105(92 ; n=5)$ long. Sclerotised accessory piece $30-34(32 ; n=5)$ long, hook-shaped, with middle process $6-7(6 ; n=4)$ long, and distally bifurcate. Gonads overlapping. Testis dorsal, slightly visible at posterior end of germarium; vas deferens loops left caecum and dilates to form seminal vesicle. Prostatic reservoir ovoid, near to proximal part of copulatory tube. Vagina opening dextrally, cone-shaped with coiled distal part, slightly sclerotised, connected to medial seminal receptacle anterior to germarium. Germarium with irregular margin. Oviduct, ootype and uterus not observed. Vitellarium scattered throughout trunk, except regions of reproductive organs.

Type host: Satanoperca jurupari (Heckel, 1840).

Site of infection: Gills.

Type locality: Araguari River at Ferreira Gomes $\left(0^{\circ} 52^{\prime} \mathrm{N}\right.$, $\left.51^{\circ} 12^{\prime} \mathrm{W}\right)$, State of Amapá, Brazil.

Prevalence: $50 \%$ (4 from 8 fish examined)

Intensity of infection: $1-2$

Specimens deposited: Holotype CHIOC no. 38092a, 2 paratypes CHIOC no. $38092 b$, c; 1 paratype IPCAS no. M-604.

Etymology: The new species is named in honour to Edgar Fernando Mendoza-Franco (Universidad Autónoma de Campeche, Mexico) for his contribution to the knowledge of dactylogyrids in Neotropical freshwater fishes.

\section{Remarks}

Sciadicleithrum Kritsky, Thatcher and Boeger, 1989 accommodates dactylogyrids possessing overlapping gonads, a coiled male copulatory organ with 1 to more rings, unmodified anchors, a ventral bar with umbelliform membranes or cavities on the anterior bar margin, and similar marginal hooks with undilated shanks and erected thumb (Kritsky et al. 1989). Bellay et al. (2009) amended the generic diagnosis to include the presence of longitudinal lateral grooves on the shafts and points of ventral and dorsal anchors, variation in the size of the hooks pairs, dorsal bar with umbelliform membranes, median projection in bars and $\mathrm{MCO}$ with more than two rings.

At present, 24 valid species of Sciadicleithrum are known, all of them described from Neotropical cichlid fishes, but only two of them having been reported from species of Satanoperca Günther, 1862, namely Sc. juruparii Melo, Santos and Santos, 2012 from Sa. jurupari in the Guamá River, Amazon Basin (Melo et al. 2012), and Sc. satanopercae from Sa. pappaterra (Heckel, 1840) in the River Paraná, Paraná Basin, South America (Bellay et al. 2009; Yamada et al. 2009). 
Of these species, Sciadicleithrum edgari n. sp. most resembles Sc. satanopercae by having a male copulatory organ with $2 \frac{1}{2}$ rings and by the presence of a distally bifurcated accessory piece. However, Sc. edgari n. sp. differs from this species by the morphology of the accessory piece, hook-shaped with a middle process and distally bifurcate versus not bifurcated in Sc. satanopercae, which was also confirmed in the present paper by a study of the holotype of the latter species (CHIOC 37165a). In addition, Sc. satanopercae has a median process on the ventral bar called 'denticulum' (Yamada et al. 2009, confirmed also by observation of paratypes CHIOC 37166a and 37167), whereas this process is absent in the new species. Sciadicleithrum edgari $\mathrm{n}$. sp. and Sc. satanopercae can be also easily distinguished by the morphology of the anchors. Sciadicleithrum edgari n. sp. can be distinguished of Sc.juruparii by having $2 \frac{1}{2}$ rings of the $\mathrm{MCO}$ and the absence of a median process on the ventral bar versus $31 / 2$ rings and a median process present.

Based on the morphology of the male copulatory organ, the new species closely resembles three other species, namely Sc. meekii Mendoza-Franco, Scholz and VidalMartínez, 1997 from Thorichthys meeki (Brind, 1918) in Mexico; Sc. splendidae Kritsky, Vidal-Martínez and Rodríguez-Canul, 1994 from Petenia splendida Günther, 1862 (type-host), Parachromis friedrichsthalii (Heckel, 1840) and P. managuensis (Günther, 1867) in Mexico; and Sc. umbilicum Kritsky, Thatcher and Boeger, 1989 from Cichla ocellaris Bloch and Schneider, 1801 in Brazil (Kritsky et al. 1989, 1994; Mendoza-Franco et al. 1997, 2000). However, Sc. edgari n. sp. differs from these species and all other congeners by the morphology of the hook-shaped accessory piece of the male copulatory organ with a middle process and distally bifurcate.

This is the third Sciadicleithrum species described from the genus Satanoperca and it is the first dactylogyrid monogenean reported from cichlids in the River Araguari basin.

\section{Sciadicleithrum araguariensis n. sp. (Fig. 2 A-G)}

Description (based on 12 specimens): Body fusiform, 412-430 $(419 ; n=8)$ long including haptor; greatest width 90-102 (95; $\mathrm{n}=6$ ), at opening of vagina. Anterior region with 3 bilateral pairs of head organs; cephalic glands indistinct. Eyespots 4; accessory granules absent. Pharynx spherical 21-24 $(22 ; n=4)$ in diameter; oesophagus short; intestine bifurcates closely posterior to pharynx; caeca confluent posterior to testis, without diverticula. Haptor globose, $40-48(43 ; n=8)$ wide. Ventral anchor 24-28 (26; $n=7)$ long, with elongate superficial root, poorly developed deep root, evenly curved shaft and point; base width 21-24 (22; $=7)$. Dorsal anchor 31-39 (34; $=7)$ long, with with elongate superficial root, evenly curved shaft and point; base width 30-34 (32; $n=6)$. Ventral bar 29-34 (31; $n=$ 4) long, yoke-shaped, with delicate umbelliform membranes. Dorsal bar 21-25 (22; $\mathrm{n}=5)$ long, robust, with enlarged ends, and delicate umbelliform membranes. Hooks 14, similar, each with erect thumb, delicate shaft and point, FH loop $3 / 4$ shank length; total length $12-16(14 ; n=9)$. Male copulatory organ (MCO) comprising a delicate coil of 2 counterclockwise rings with diameter of proximal coil 14-16 $(14 ; n=4)$ long; copulatory tube with $92-104(100 ; n=4)$ long. Sclerotised accessory piece $38-42(40 ; n=5)$ long, Y-shaped, proximally bent. Gonads overlapping. Testis dorsal, slightly visible at posterior end of germarium; vas deferens loops left caecum and dilates to form seminal vesicle; prostatic reservoir ovoid, near to proximal part of copulatory tube. Vagina opening ventrally, comprising a delicate tube, slightly sclerotised, connected to medial seminal receptacle anterior to ovary. Germarium with irregular margin. Oviduct, ootype and uterus not observed. Vitellarium scattered throughout trunk, except regions of reproductive organs.

Type host: Crenicichla labrina (Spix and Agassiz, 1831).

Site of infection: Gills.

Type locality: Araguari River in Ferreira Gomes $\left(0^{\circ} 52^{\prime} \mathrm{N}\right.$, $\left.51^{\circ} 12^{\prime} \mathrm{W}\right)$, State of Amapá, Brazil.

Prevalence: $100 \%$ (1 from 1 fish examined).

Intensity of infection: 12

Specimens deposited: Holotype CHIOC no. 38091a; 2 paratypes CHIOC no. 38091 b, c, d; 1 paratype IPCAS no. M605.

Etymology: The specific name araguariensis refers to the type locality.

\section{Remarks}

Based on the shape and size of anchors and bars and the dextral vagina, Sciadicleithrum araguariensis $\mathrm{n}$. sp. most closely resembles Sc. joanae, a species described from Crenicichla niederleinii (Holmberg, 1891) and C. britskii Kullander, 1982 in the River Paraná, Brazil, South America (Yamada et al. 2009). Both species can be distinguished by the following characteristics: the copulatory tube in $S c$. araguariensis n. sp. comprises a delicate coil of two counterclockwise rings, whereas it is about half a clockwise loop and winding distal portion in Sc. joanae (confirmed in the present paper by the study of the holotype CHIOC 37161 and paratype CHIOC 37163a). In addition, the vagina of Sc. joanae has a 'bulbshaped' structure near its aperture (Yamada et al. 2009), whereas it comprises a delicate, slightly sclerotised tube in $S c$. araguariensis $\mathrm{n} . \mathrm{sp}$.

The morphology of the ventral bar (yoke-shaped, with delicate umbelliform membranes) of the new species closely resembles that of six other species, namely Sc. aequidens (Price and Schlueter, 1967) and Sc. cavanaughi (Price, 1966) from Cleithracara maronii (Steindachner, 1881) in the Republic of Guiana; Sc. iphthimum Kritsky, Thatcher and Boeger, 1989 from Pterophyllum scalare (Lichtenstein, 1823); Sc. tortrix Kritsky, Thatcher and Boeger, 1989 from Uaru amphiacanthoides Heckel, 1840; Sc. variabilum (Mizelle and Kritsky, 1969) from Symphysodon discus Heckel, 1840, all in Brazil; 
and Sc. bravohollisae Kritsky, Vidal-Martínez and RodríguezCanul, 1994 from Cichlasoma pearsei (Hubbs, 1936) in Mexico, North America (Kritsky et al. 1989, 1994; Bellay et al. 2009). However, Sc. araguariensis n. sp. differs from these species and all other congeners, including Sc. edgari, by a Yshaped accessory piece of the male copulatory organ.

Sciadicleithrum araguariensis $\mathrm{n}$. $\mathrm{sp}$. is the first parasite reported from Crenicichla labrina.

\section{New host and geographical records}

In addition to two new species of Sciadiclethrum described above, another six species of gill monogeneans of the family Dactylogyridae were found during parasitological surveys carried out in the Xingu River (State of Pará) in April 2013 and the Araguari River (State of Amapá), Brazil in May 2013; most of them represent new host and geographical records (see

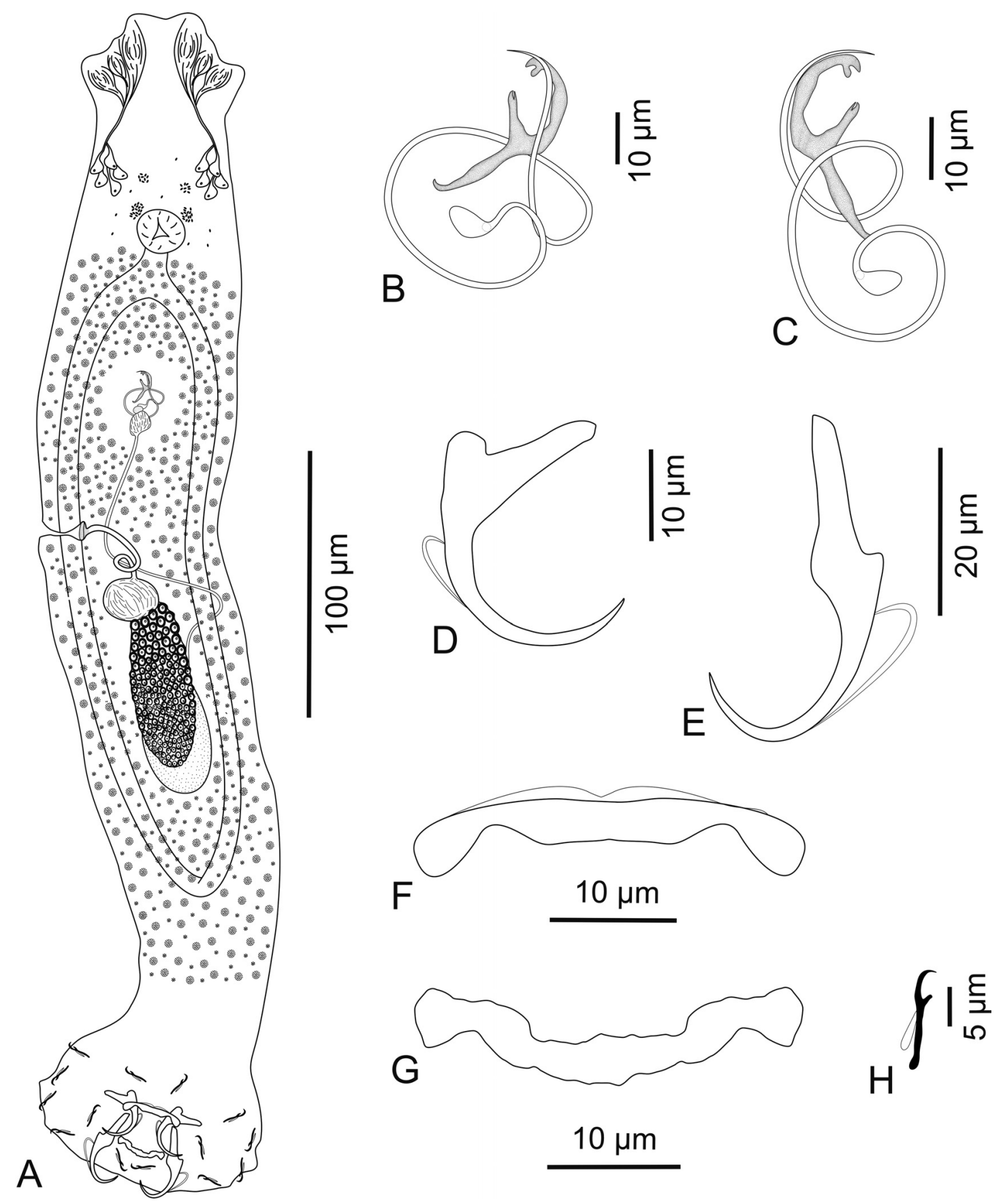

Fig. 1. Sciadicleithrum edgari n. sp. from Satanoperca jurupari. A - whole-mounted specimen, ventral view; B, C - copulatory complex, ventral and dorsal view, respectively; D - ventral anchor, ventral view; $\mathbf{E}$ - dorsal anchor, ventral view; F - ventral bar, ventral view; G - dorsal bar, ventral view; H - Hook 
Table I). In the Xingu River in Altamira $\left(3^{\circ} 12^{\prime} \mathrm{S}, 52^{\circ} 12^{\prime} \mathrm{W}\right)$, the following monogeneans were found on 43 cichlid fish of 7 species: Gussevia undulata Kritsky, Thatcher and Boeger, 1986, Sciadicleithrum umbilicum Kritsky, Thatcher and Boeger, 1989, Sc. uncinatum Kritsky, Thatcher and Boeger, 1989 and Tucunarella cichlae Mendoza-Franco, Scholz and Rozkošná, 2010 on Cichla melaniae Kullander and Ferreira, 2006; Sciadicleithrum geophagi Kritsky, Thatcher and Boeger,
1989 on Geophagus altifrons Heckel, 1840 and Geophagus argyrostictus Kullander, 1991; and Sciadicleithrum satanopercae on Satanoperca sp.

In the Araguari River, five species of dactylogyrid monogeneans were found on 35 cichlids of four species besides the two above described new species of Sciadicleithrum, namely Gussevia undulata, Sciadicleithrum umbilicum and Sc. uncinatum on Cichla temensis Humboldt, 1921; Sciadicleithrum
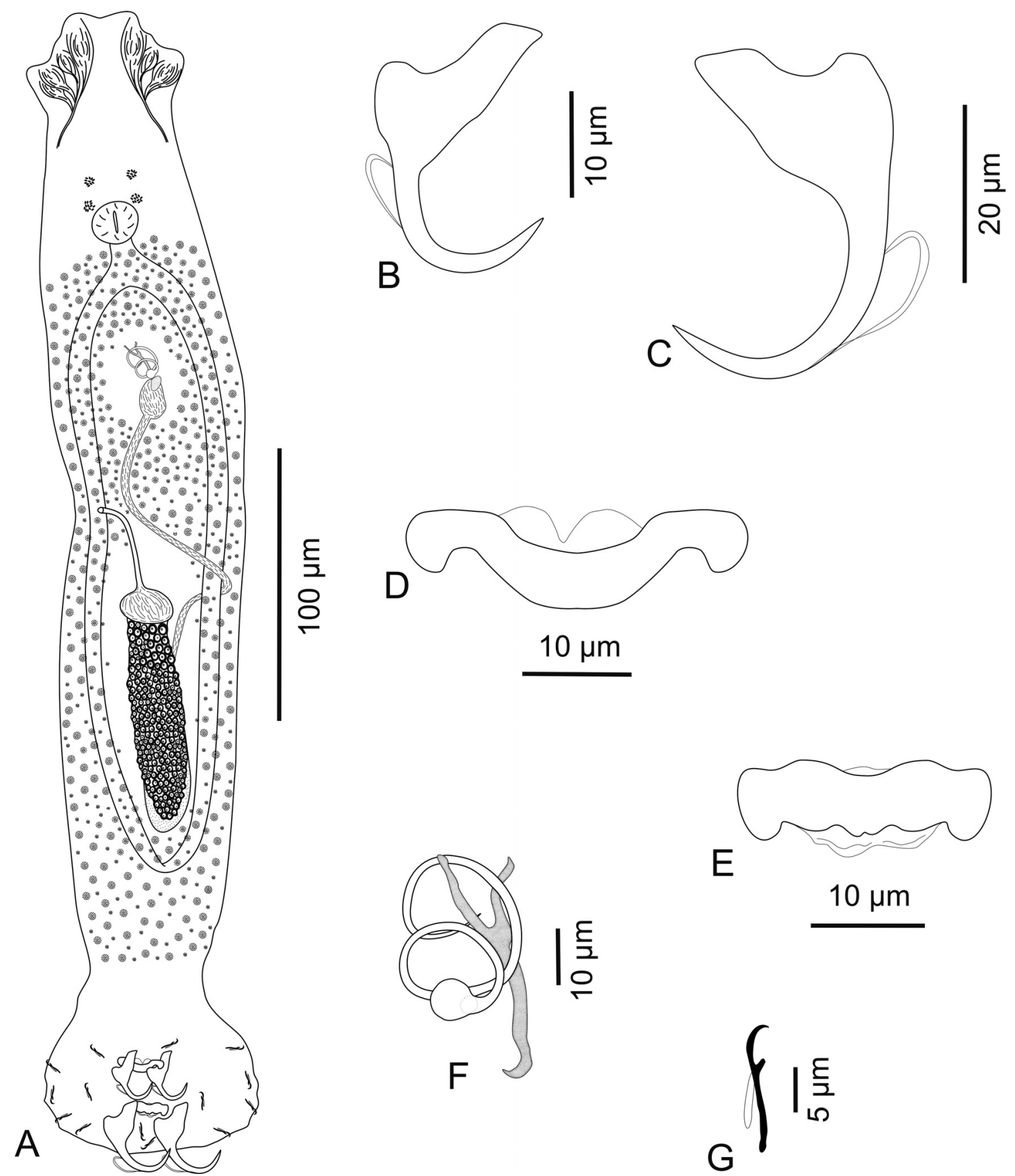

Fig. 2. Sciadicleithrum araguariensis n. sp. from Crenicichla labrina. A - whole-mounted specimen, ventral view. B - ventral anchor, ventral view; $\mathbf{C}$ - dorsal anchor, ventral view; D - ventral bar, ventral view; $\mathbf{E}$ - dorsal bar, ventral view; $\mathbf{F}$ - copulatory complex, ventral view; $\mathbf{G}$ - hook 
Table I. New host and geographical records of dactylogyrids of cichlids found in the present study

\begin{tabular}{|c|c|c|c|c|}
\hline Species of monogeneans & Known hosts & New host records & $\begin{array}{l}\text { New geographical } \\
\text { records (River) }\end{array}$ & References \\
\hline $\begin{array}{l}\text { Gussevia undulata } \\
\text { CHIOC*No } 38099 \\
\text { IPCAS No M-609 }\end{array}$ & $\begin{array}{l}\text { Cichla ocellaris } \\
\text { Cichla kelberi } \\
\text { Cichla monoculus }\end{array}$ & $\begin{array}{l}\text { Cichla melaniae } \\
\text { Cichla temensis }\end{array}$ & Xingu, Araguari, Brazil & $\begin{array}{l}\text { Cohen et al. (2013) } \\
\text { Mendoza-Franco et al. } \\
(2010)\end{array}$ \\
\hline $\begin{array}{l}\text { Sciadicleithrum geophagi } \\
\text { CHIOC No 38093, } 38094 \\
\text { IPCAS No M-606 }\end{array}$ & Geophagus surinamensis & $\begin{array}{l}\text { Geophagus altifrons } \\
\text { Geophagus argyrostictus } \\
\text { Geophagus proximus }\end{array}$ & Xingu, Araguari, Brazil & Kritsky et al. (1989) \\
\hline $\begin{array}{l}\text { Sc. uncinatum } \\
\text { CHIOC No } 38098 \\
\text { IPCAS No M-608 }\end{array}$ & Cichla ocellaris & $\begin{array}{l}\text { Cichla temensis } \\
\text { Cichla melaniae }\end{array}$ & Xingu, Araguari, Brazil & Kritsky et al. (1989) \\
\hline $\begin{array}{l}\text { Tucunarella cichlae } \\
\text { CHIOC No } 36311\end{array}$ & Cichla monoculus & Cichla melaniae & Xingu, Brazil & $\begin{array}{l}\text { Mendoza-Franco et al. } \\
\text { (2010) }\end{array}$ \\
\hline
\end{tabular}

*CHIOC - Coleção Helmintológica do Instituto Oswaldo Cruz, Rio de Janeiro; IPCAS - Helminthological Collection of the Institute of Parasitology, Biology Centre of the Czech Academy of Sciences

geophagi on Geophagus proximus (Castelnau, 1855); and Sciadicleithrum satanopercae on Satanoperca jurupari. All fishes except Satanoperca jurupari represent new hosts of these monogeneans (see Table I) and all parasites are reported from the Araguari River for the first time.

\section{Discussion}

The present study provides the first data on monogeneans parasitising cichlid fishes in two rivers in northern Brazil. Eight species of dactylogyrid monogeneans of three genera were found on cichlid fishes of the genera Cichla Bloch and Schneider, 1801, Crenicichla Heckel, 1840, Geophagus Heckel, 1840 and Satanoperca, namely six species of Sciadicleithrum including two new taxa, and one species of Gussevia and Tucunarella each.

The monogeneans found on cichlids from the Xingu River have been previously recorded in the Amazon River basin (Kritsky et al. 1986, 1989; Mendoza-Franco et al. 2010). The most remarkable is the first record of Tucunarella cichlae from Brazil, because this species was known only from the type locality in the Peruvian Amazon (Mendoza-Franco et al. 2010) and the present finding considerably expands its distribution area. In contrast, the fauna of fish of the Araguari River, which is $300 \mathrm{~km}$ long and empties to the Atlantic Ocean $12 \mathrm{~km}$ northwest of the Amazon estuary, has not been studied and nothing was also known about fish parasites in this river before the present study.

Gussevia undulata, Sciadicleithrum umbilicum and Sc. uncinatum were originally described from 'Cichla ocellaris' from the Negro River in Manaus, Amazon Basin, in Brazil; Cichla melaniae and C. temensis are their new hosts. However, several species of Cichla previously identified as C. ocellaris have been recently recognised as separate taxa (see Kullander and Ferreira 2006). In fact, the distribution area of C. ocellaris is limited to Guayanas, whereas a number of other species such as C. monoculus Agassiz, 1831, C. melaniae and C. temensis occur in the River Amazon basin (Kullander and Ferreira 2006).

At present, 26 valid species of Sciadicleithrum are recognised including two new species of Sciadicleithrum described in the present paper. Bellay et al. (2009) presented some morphological characteristics shared by species of this genus occurring in the same geographical areas, such as the number of rings of the male copulatory organ (MCO). However, two new species described herein more resemble congeners from Central America and southeastern Mexico in the number of rings in the MCO and in the morphology of connecting bars and anchors, similarly as some other species described in Brazil, e.g. Sc. juruparii and Sc. satanopercae (see Yamada et al. 2009; Melo et al. 2012).

Mendoza-Franco et al. (2010) pointed out a relatively low host specificity of species of Sciadicleithrum, mainly those parasitising cichlids of the genera Cichla, Cichlasoma Swainson, 1839 and Satanoperca, compared to other groups of gill monogeneans of the family Dactylogyridae. The number of new hosts of three species of Sciadicleithrum found in the present study (Table I) supports this assumption because some of these species are probably stenoxenous, i.e. they occur in several congeneric species of fish hosts. However, a high num- 
ber of cichlids occurring in the Neotropical Region have not yet been examined for parasites and thus more data are necessary before the actual species richness and host-parasite associations of their gill monogeneans are sufficiently described.

Acknowledgments. We wish to thank Aristides Ferreira Sobrinho, Aldenice de Nazaré Pereira, Philippe Vieira Alves and Vivian Freitas Vieira for help with collecting fish and their parasitological examination and Emil José Hernández Ruz, Universidade Federal do Pará - Altamira, for providing the facilities during the field trip. This study was partly supported by the 'Ciência sem fronteiras' Brazilian program - visitant researcher modality (No. 135/2012) (stay of T. Scholz in Brazil at the Universidade Federal Rural de Rio de Janeiro) and Conselho Nacional de Desenvolvimento Científico e Tecnológico (CNPq) grants to J. L. Luque (Nos. 474077/2011-0, 304254/2011-8, 402665/2012-0), the Institute of Parasitology (RVO 60077344) and the Czech Science Foundation (P505/12/G112). Fabiano Paschoal was supported by a student fellowship from Coordenação de Aperfeiçoamento de Pessoal do Ensino Superior (CAPES), Brazil.

\section{References}

Bellay S., Takemoto R.M., Yamada F.H., Pavanelli G.C. 2009. Two new species of Sciadicleithrum (Monogenea: Dactylogyridae), gill parasites of Geophagus proximus (Castelnau) (Teleostei: Cichlidae), from the upper Paraná River floodplain, Brazil. Zootaxa, 2081, 57-66

Braga M.P., Araújo S.B.L., Boeger W.A. 2014. Patterns of interaction between Neotropical freshwater fishes and their gill Monogenoidea (Platyhelminthes). Parasitology Research, 113, 481-490. DOI: $10.1007 / \mathrm{s} 00436-013-3677-8$

Cohen S.C., Justo M.C., Kohn A. (Eds.). 2013. South American Monogenoidea Parasites of Fishes, Amphibians and Reptiles. Oficina de Livros, Rio de Janeiro, pp. 663

Ergens R. 1969. The suitability of ammonium picrate-glycerin in preparing slides of lower Monogenoidea. Folia Parasitologica, 16,320

Froese R., Pauly D. (Eds.) 2014. FishBase. World Wide Web electronic publication. Available at: $<$ www.fishbase.org $>$, version 11/2014. Accessed in: March 2015

Kritsky D.C., Boeger W.A., Thatcher V.E. 1985. Neotropical Monogenea. 7. Parasites of the pirarucu Arapaima gigas (Cuvier), with descriptions of two new species and redescription of Dawestrema cycloancistrium Price and Nowlin, 1967 (Dactylogyridae: Ancyrocephalinae). Proceedings of the Biological Society of Washington, 98, 321-331

Kritsky D.C., Boeger W.A., Thatcher V.E. 1986. Neotropical Monogenea. 8. Revision of Urocleidoides (Dactylogyridae, Ancyrocephalinae). Proceedings of the Helminthological Society of Washington, 53, 1-37

Kritsky D.C., Thatcher V.E., Boeger W.A. 1989. Neotropical Monogenea. 15. Dactylogyrids from the gills of Brazilian Cichlidae with proposal of Sciadicleithrum gen. n. (Dactylogyridae). Proceedings of the Helminthological Society of Washington, $56,128-140$

Received: April 2, 2015

Revised: September 16, 2015

Accepted for publication: October 12, 2015
Kritsky D.C., Vidal-Martínez V.M., Rodríguez-Canul R.P. 1994. Neotropical Monogenoidea 19. Dactylogyridae of cichlids (Peciformes) from the Yucatan Peninsula, with descriptions of three new species of Sciadicleithrum. Journal of the Helminthological Society of Washington, 61, 26-33

Kullander S.O., Ferreira E.J.G. 2006. A review of the South American cichlid genus Cichla, with descriptions of nine new species. Ichthyological Exploration of Freshwaters, 17, 289398

Malmberg G. 1957. Om förekomsten av Gyrodactylus pau svenska fiskar. Särtryck ur Skrifter utgivna av Södra Sveriges Fiskeriförening, Arsskrift, 1956, 19-76

Melo M.F.C., Santos J.N., Santos C.P. 2012. Sciadicleithrum juruparii n. sp. (Monogenea: Ancyrocephalidae) from the gills of Satanoperca jurupari (Heckel) (Osteichthyes: Cichlidae) in the Guamá River, Amazon Delta, Brazil. Systematic Parasitology, 82, 125-129. DOI: 10.1007/s11230-012-9353-z

Mendoza-Franco E.F., Scholz T., Rozkošná P. 2010. Tucunarella n. gen. and other dactylogyrids (Monogenoidea) from cichlid fish (Perciformes) from Peruvian Amazonia. Journal of Parasitology, 96, 491-498. DOI: 10.1645/ge-2213.1

Mendoza-Franco E.F., ScholzT., Vidal-Martínez V.M. 1997. Sciadicleithrum meeki sp. n. (Monogenea: Ancyrocephalinae) from the gills of Cichlasoma meeki (Pisces: Cichlidae) from cenotes ( $=$ sinkholes) in the Yucatan Peninsula, Mexico. Folia Parasitologica, 44, 205-208

Mendoza-Franco E.F., Vidal-Martínez V.M., Aguirre-Macedo M.L., Rodríguez-Canul R., Scholz T. 2000. Species of Sciadicleithrum (Dactylogyridae: Ancyrocephalinae) of cichlid fishes from southeastern Mexico and Guatemala: new morphological data and host and geographical records. Comparative Parasitology, 67, 85-91

Mendoza-Palmero C.A., Scholz T., Mendoza-Franco E.F., Kuchta R. 2012. New species and geographical records of dactylogyrids (Monogenea) of catfish (Siluriformes) from the Peruvian Amazonia. Journal of Parasitology, 98, 484-497. DOI: 10. 1645/ge-2941.1

Ortega H., Guerra H., Ramírez R. 2007. The introduction of nonnative fishes into freshwater systems of Peru. In: (Ed. T. M. Bert), Ecological and genetic implications of aquaculture activities, New York: Springer, 6, 247-278. DOI: 10.1007/9781-4020-6148-6

Perez-Sanchez E., Páramo-Delgadillo S. 2008. The culture of cichlids of southeastern Mexico. Aquaculture Research, 39, 777783. DOI: 10.1111/j.1365-2109.2008.01929.x

Vidal-Martínez V.M., Aguirre-Macedo M.L., Scholz T., GonzálezSolís D., Mendoza-Franco E.F. 2001. Atlas of the helminth parasites of cichlid fish of Mexico. Praha: Academia, pp. 165

Thatcher V.E. 2006. Amazon fish parasites, 2nd ed. Bulgaria: Pensoft, Sofia, pp. 508

Yamada F.H., Takemoto R.M., Bellay S., Pavanelli G.C. 2009. Two new species of Sciadicleithrum (Monogenea: Dactylogyridae) parasites of Neotropical cichlid fishes from the Paraná River, Brazil. Acta Parasitologica, 54, 6-11. DOI: 10.2478/s11686009-0004-8 